\title{
Audiovisual dialectology \\ The film research project "Documentary records of past folk culture in dialect" and its role in the linguistic culture of Carinthia
}

\author{
Herta Maurer-Lausegger \\ Institute of Slavic Studies, University of Klagenfurt, Austria
}

Am Institut für Slawistik der Universität Klagenfurt läuft seit 1994 ein dialektologisch-ethnologisches Filmprojekt mit dem Titel "Dokumentation alter Volkskultur im Dialekt", das die Sprache zweisprachiger Dialektsprecher aus dem südlichen Kärnten auf Video festhält und Dokumentarfilme produziert. Im Mittelpunkt des Interesses steht spontan gesprochene Mundart in simuliert natürlicher Sprechsituation. Erfahrungs- und Erlebnisberichte aus dem handwerklich geprägten bäuerlichen Alltag werden in Form von Dialogen und Gruppengesprächen, aber auch als Einzelaufnahmen auf Video festgehalten. Seit November 1998 bilden Terminologiedokumentationen aus der traditionellen bäuerlichen Welt einen besonderen Schwerpunkt. Die Methodologie der audiovisuellen Dialektologie wurde von der Projektleiterin (Verfasserin dieses Aufsatzes) gemeinsam mit einem professionellen Filmteam erarbeitet. Die bisherigen Filmeinheiten konzentrieren sich auf folgende Fachbereiche: Wassermühlen und Sägen, Schafzucht, Bauerngerät für den Ackerbau, Schlitten und Holzabtransport mit dem Bockschlitten, Brotbacken in der Rauchküche und anderes. Die Videofilme erscheinen gemeinsam mit begleitenden Textbeilagen in der Projektserie "Dialektdokumentationen - Narečne dokumentacije" beim Hermagoras Verlag in Klagenfurt. Filmausschnitte aus den Videos sind auf der Homepage des Projekts www.kwfilm. com abrufbar. - Die audiovisuelle Dokumentation ethnographischer Themen in slowenischen und deutschen Dialekten Kärntens verfolgt linguistische, kulturwissenschaftliche und soziokulturelle Ziele. Durch zahlreiche Filmpräsentationen im Rahmen des Kärntner Kulturangebots wird bei der deutschsprachigen Mehrheitsbevölkerung die Loyalität gegenüber der Minderheitensprache und -kultur gestärkt, aber auch auf die aussterbenden, kulturellen Werte aufmerksam gemacht. Es bleibt zu hoffen, dass dieser positive Trend in einem Europa der Sprachen und Kulturen zum Vorteil aller fortgesetzt wird.

\section{INTRODUCTION}

As an important sociocultural factor, audiovisual media exert a significant influence on interpersonal communication and linguistic culture within a society. In the Western world, all social classes - even in geographically remote areas - have achieved certain social standards and technological levels within the past few decades. The influence of 
public media on the linguistic culture of a society is especially apparent in bilingual situations, particularly in cases where the language of the majority is clearly dominant, as is the case in Carinthia. In my paper I would like to introduce the research project "Documentary records of past folk culture in dialect" and then illustrate how commercial videos in Slovene and German dialect can influence the linguistic culture of bilingual Carinthia.

One of the characteristic features of the southern part of Carinthia is that Slovenespeaking and German-speaking inhabitants have lived there side by side for centuries. Its remote geographical position and very varied landscapes coupled with its subdivision by the church into administrative units (following the borders of the original parishes) have facilitated the development of a great variety of different dialects and vernaculars. This is reflected in an old saying: "Every village has a language of its own."

In bilingual Carinthia the field researcher is confronted with an extremely delicate sociolinguistic situation (cf. Maurer-Lausegger 1995, 1996, 1998). Historical and political events, the fact that the population has not yet fully come to terms with its past, a language policy clearly putting the minority at a disadvantage and permanent pressure to assimilate exerted by the German-speaking majority: several decades ago all of these factors caused an ethnic division of the Slovene minority into a fraction that still strongly emphasizes its Slovene roots and a German-friendly fraction called "Windische". The latter have lost their Slovene identity: they still use the Slovene vernacular alongside German - this applies especially to the older generations - but they do not feel emotionally attached to the Slovene language and culture. ${ }^{1}$ In order to obtain representative dialectological and sociolinguistic data in this region, it is necessary to be fully aware of these potentially problematic circumstances.

\section{The Research PROJeCt "DocumentaRy ReCORDS of Past folk CUlture IN DIALECT" - WWW.kwfilm.com}

In 1994 a dialectological and ethnological film project was launched by the Institute of Slavic Studies at the University of Klagenfurt under the heading "Documentary records of past folk culture in dialect". It involves recording the language of bilingual dialect speakers from the southern parts of Carinthia and then producing documentary video films. The main aim of the project is audiovisual dialectology but it is also part of a project initiated by Univ.Prof. Dr Gerhard Neweklowsky in 1984 entitled "Research on Slovene dialects in Carinthia", responsibility for which was taken over by dialect researcher Dr Herta Maurer-Lausegger in 1994. The audiovisual documentaries have been produced both in cooperation with ARTIS Filmproduktions-GesmbH (since 1998), a Klagenfurt film company, and the Institute of Media and Communication Studies at the University of Klagenfurt (1994-1998).

The techniques of "audiovisual dialectology" have been developed in close cooperation with expert film makers in the course of this project. The first general definition of the concept behind it dates back to 2000 and states: 


\begin{abstract}
"The use of video technology in dialectological field work is a method of documenting linguistic and cultural matters synchronically which allows the viewer to hear the spoken dialect as well as other sounds and noises and to observe the production of spontaneous speech from a realistic perspective which also includes nonverbal communication and the social context. The chronological sequences of pictures on the video can be reproduced so that this process of hearing and observing can be experienced and analysed at any time and in every location where the appropriate technical equipment is available. The more often and the more intensively this process takes place, the more profoundly this realistic context can be tapped into" (Maurer-Lausegger 2000). ${ }^{2}$
\end{abstract}

The visual aspect provides contextual information on nonverbal communication with its very heterogeneous paralinguistic and extralinguistic phenomena alongside and simultaneously with the text, very often proving to be an indispensable aid to interpreting the text or the facts. In this way the dialectological sound track plus images and the ensuing documentary film demand a very high degree of processing from the recipients. Audiovisual data represent a complicated interweaving of interrelated semantic and semiotic elements which complement each other, endowing the meaning of the text in a classical sense with an additional, more profound dimension (cf. MaurerLausegger 2000).

\title{
2.1. Subject and methodology
}

\subsection{1.}

The videos produced in the context of the project mainly focus on ethnological issues. Bilingual speakers talk about different kinds of agricultural work they are familiar with. This kind of documentation gives future generations a comprehensive insight into the dialectological and ethnographic features of a region. Since November 1998, the research project has concentrated on documenting both agricultural/rural terminology and the actual objects in audiovisual form, the main aim being to record spontaneous spoken dialect in simulated yet natural situations. Observations and experiences from everyday rural life, which is still characterized by the use of traditional farming skills and implements, are recorded on video in the form of dialogues and group conversations as well as monologues.

\subsection{2.}

The methodology applied for the purpose of audiovisual documentation of dialects has been developed by the project leader (the author of the present paper), taking into account the relevant literature on the topic and, in particular, her personal experience in this particular area. Classical dialectological interviewing methods were supplemented by sociolinguistic, sociological, ethnographic and audiovisual components and adapted to the specific recording situation. Naturally, one of the top priorities of every field researcher setting out to record spoken dialect is to adequately prepare the dialect 
speaker or group of dialect speakers for a simulated yet natural interview in front of the camera and to maintain a natural and relaxed atmosphere throughout, which requires a good deal of sensitivity and intuitive understanding (cf. Maurer-Lausegger 1995, 1996, 1997, 1998).

A researcher setting out to produce representative audiovisual dialect documentation with a video camera must be thoroughly familiar with the sociolinguistic situation in the chosen geographical area. The methodological approach of the field team always depends on local circumstances, which means that the complex sociolinguistic situation of Carinthia requires great flexibility in this respect.

\subsubsection{Audiovisual documentation of terminology and objects from the perspective of contextual research: a new methodological approach}

Several ethnographic exhibitions arranged by the author in the village where she comes from, Bodental/Poden (municipality of Ferlach/Borovlje), on the topic of old farm implements prompted her to expand the audiovisual dialectological documentary project to include research into terminology and the objects being described. Specialist fields of life are recorded on video with a running commentary on the objects which are being used/explained. The aim is to record ethnographic circumstances and spoken dialect simultaneously while being as authentic as possible. In order to achieve this ambitious research work, which requires a very good interview partner/dialect speaker and skilled camera work, the Klagenfurt film company ARTIS FilmproduktionsGesmbH was brought into the project. So far three ethnographic video films on old farm implements have been made in cooperation with this team of professionals: "Farm implements from Carinthian lofts" (1999), "About sledges ..." (1999-2001) and "Bread from the black kitchen" (1999-2000).

\subsection{Video films and accompanying pamphlets}

The videos which have been produced from the materials recorded so far concentrate on the following specialist fields: water mills and sawmills, sheep breeding, agricultural implements for arable farming, sledges and transporting wood, baking bread in the black kitchen. Six documentaries in all have been compiled on these topics, each in Slovene and in German and two with English subtitles, published along with an accompanying pamphlet by Hermagoras Verlag in Klagenfurt as part of a special series entitled "Dialektdokumentationen - Narečne dokumentacije" (Documentaries in dialect). The German versions of the documentaries were either originally recorded in German as well or have been dubbed. The Slovene versions of the films on sledges and on baking bread in the black kitchen have also been brought out with English subtitles. Short extracts from the videos can be viewed on the internet at www.kwfilm.com.

The accompanying pamphlets, which are illustrated with old photographs, have a phonological transcription of the text of the film and a German translation or a standard Slovene version. They also include detailed information on how the individual films were made. 
There now follows a brief description of the individual film projects which have already been produced and made available to the general public as commercial films. The first three projects (cf. 2.2.1., 2.2.2. and 2.2.3.) were made with a German-speaking cameraman at the University of Klagenfurt. They present unscripted dialogues and/or monologues with people from different generations. The next three projects (cf. 2.2.4., 2.2.5. and 2.2.6.) were carried out in cooperation with a bilingual (Slovene and German) professional film company in Klagenfurt. In these films the dialect and the objects being talked about are filmed at the same time with maximum authenticity, the main aim being to document the terminology audiovisually.

\subsection{1. "The dialect in the shadow of the Vertascha. Mills and sawmills" (1994)}

This film records three groups of speakers (two groups of three and one of two) freely conversing in dialect. The objects and places to which the conversations refer were filmed separately.

Elderly bilingual people from Windisch Bleiberg/Slovenji Plajberk and Bodental/Poden talk about what life used to be like in the valley of mills and saws. The once indefatigable sound of mill wheels turning is no longer to be heard, and many traces of old farming traditions have already disappeared. The local speech in Bodental and Windisch Bleiberg is also exposed to inevitable change: the generation whose work and scant leisure time used to be accompanied by the steady clacking of mills can now only talk about their memories.

2.2.2. "Barbara, Luzia, help us ... water mills in Diex. Made for the occasion of its 1100th anniversary" (1995)

On the southern slopes of the Saualpe in Carinthia lies the village of Diex/Djekše, the sunniest place in Austria. No wonder the inhabitants of Diex also have a sunny character. The older generation can still speak both local languages (German and Slovene) and can remember the times when the village economy depended on flour mills. The video is a documentation of the only water mill which was still operating in 1995. It is also a linguistic and ethnological record of the mill trade in Diex.

This documentary was produced in two versions, Slovene and German. It records the vernacular of two older bilingual dialect speakers from the northernmost fringes of the bilingual region of Carinthia. The dialogue was recorded near an old water mill. Most of the work processes in the mill are described by just one of the speakers, the owner of the mill himself.

2.2.3. "Sheep breeding without borders: linguistic and ethnographic observations in southern Carinthia. A contribution to the Carinthian District Exhibition 1997" (1996)

There are over twenty endangered breeds of domestic animal in Austria. One of these, a "spectacled" breed of sheep, can still be found in the part of southern Carinthia bordering on Slovenia. In the video film, bilingual representatives of four generations 
from Bodental and Windisch Bleiberg tell us about sheep breeding in former times (wool had to be washed, sheep sheared, and the yarn spun) and nowadays when things have become simpler and faster.

The text and images were recorded separately. This video film is not only intended to help revive the breeding of spectacled sheep, but also to help preserve the rich terminology connected with this field.

\subsection{4. "Farm implements from Carinthian lofts" (1999)}

Despite its geographic position on the fringes of the Karawanken mountain range, life in the Bodental valley and in Windisch Bleiberg in southern Carinthia is subject to constant change. The video in the Slovene dialect of Windisch Bleiberg/Slovenji Plajberk records the ethnographic exhibition of old farm implements, "Bodental 1998", focusing on how the fields were tilled. It documents the terminology and implements with both the ethnographic circumstances and authentic speech of an older dialect speaker recorded at the same time. Deeply rooted in the rural world of the mountain farmer, Lorenz Tschertou gives his account of bygone times, based on the exhibited implements. His memories of the past alternate with precise and systematic descriptions of the implements and former working methods.

\subsection{5. "About sledges ..." (1999-2001)}

This documentary film in the Slovene dialect of Windisch Bleiberg/Slovenji Plajberk takes us back to the time when sledges of all different varieties were still used on farms. Horse-drawn sledges and wagon accessories, both light and heavy hand sledges and children's sledges are all introduced. Particular attention is paid to the harnessing of the horse and the transport of timber by horse and cart. Nowadays, it is carried out much more simply by crane. The special expressions for the implements and their operational parts are all recorded on the video with an older dialect speaker. But the protagonist also tells us quite a lot about the life of the inhabitants of the Bodental valley and Windisch Bleiberg in earlier days.

\subsection{6. "Bread from the black kitchen" (1999-2000)}

In former times, life on the farm was very closely linked with cereals. Baking bread in a tiled stove was one of the most important household tasks. The video shows bread being baked in one of the few remaining black kitchens in working order in bilingual southern Carinthia. It records the local Slovene vernacular of just one protagonist using the dialect spoken in Windisch Bleiberg in the Karawanken region and was filmed while she was actually making the bread.

Black kitchens are an element of traditional culture. A few of them have been preserved in their original form in the Karawanken region. At least here some farmhouse bread may appear on the table which has been baked in a tiled stove. 


\subsection{Project funding}

The film project receives financial support from the Research Commission at the University of Klagenfurt, the Province of Carinthia and private sponsors. Selling the documentary films and accompanying pamphlets brings in additional funds which contribute to the project's continued existence.

\section{OBJeCtiVES OF AUDIOVISUAL DIALECT DOCUMENTATION}

The main aim of the research project is to record and study the very wide range of dialects and vernaculars spoken in southern Carinthia. At the same time, valuable cultural heritage will be saved from completely dying out and preserved for posterity. On a long-term basis, the aim is to expand the project to include other specialist fields and also other text types, which could serve as a basis for research in linguistics and cultural studies.

The documentaries are also screened in public, for example as part of university courses (dialectology, ethnology), seminars, excursions, school events and cultural evenings. Dialectologists, ethnologists and other cultural studies experts are interested in these documentaries, as are experts from other disciplines as well as anybody with an interest in folklore and cultural matters. The project leader also arranges presentations at ethnographic exhibitions (especially for tourists staying in the region) and as part of various other social programmes.

\subsection{Linguistic objectives}

The main academic aim of the project is to document the local Slovene vernaculars spoken in different parts of southern Carinthia by recording the language used by bilingual speakers from different age groups. In this context the ethnic identity of the speakers is not so important. The German dialect is recorded along with the Slovene dialect, the same speaker being asked to provide the same information (subject of the interview) in both languages.

The video material is highly interesting from various academic and linguistic points of view. Alongside spontaneous spoken language, the videos also provide information about nonverbal communication and the extralinguistic context (Križnar 1991: 150 and 158). The recorded audiovisual material does not only serve as a basis for classical dialectological research but also for an investigation of pragmatic and communicationrelated levels, allowing an analysis of the communicative function(s) of the vernacular within groups of bilingual speakers in natural situations (Scheutz/Haudum 1982: 306). In addition, the bilingual video tapes are a valuable source for investigating linguistic interference and/or transference phenomena between the two languages. The fact that the speakers belong to different generations additionally offers an opportunity to look at how language changes. 


\subsection{Sociocultural and ethnological objectives}

In addition to linguistic objectives, the audiovisual documentation of ethnological topics in dialect also plays an important sociocultural role. The videos can be purchased (each in a German and a Slovene version) and are repeatedly shown in public. They arouse the audience's interest in the ethnological issues relating to both the past and present and increase interest in the phenomenon of dialect as such.

When the videos are shown at bilingual cultural events, they often stimulate an extensive discussion of terminology or the value of dialect in general. In the course of such discussions older people are often reminded of long-forgotten words and expressions. They then frequently move on to the existential threat posed to rural dialects and especially to the fact that the Slovene vernaculars spoken in Carinthia might, in fact, disappear forever one day. Many visitors who have suppressed or forgotten their Slovene mother tongue realize that they have, at the same time, lost a valuable part of their own identity and culture. It often turns out that children and grandchildren in bilingual families do not understand the language of their parents and grandparents.

\section{ThE INDIVIDUAL PROJECTS AND THEIR INFLUENCE ON LINGUISTIC CULTURE IN CARINTHIA}

As mentioned at the start, the sociolinguistic situation in Carinthia is extremely complex. For sociostructural reasons, communication in the language of the Slovene minority in Carinthia almost always stands in the shadow of German, the dominant language of the majority. The only exception to this is communication within Slovene or bilingual institutions and associations and the Slovene-language media. Although Slovene is recognized as an official language in the province and is, at present, enjoying a more positive relationship to German in both linguistic and cultural terms than was the case in the past, there are still problems with the use of Slovene in public.

The film project "Documentary records of past folk culture in dialect" has made its own contribution to increasing the general acceptance of Slovene in Carinthia thanks to its active public relations work and frequent presence in the media. Audiences at public presentations of the dubbed German versions are invariably confronted with the realities of Carinthian bilingualism. The project is now well known in numerous countries but at the beginning there were problems with a whole range of sociolinguistic factors until it also gained general acceptance with the Carinthian public as well. This process is outlined by describing the experiences gathered with each film as it was made.

\section{1.}

The first video produced for the project "Documentary records of past folk culture in dialect", a documentary film on the mills and sawmills of Bodental - "Narečje pod Vrtačo. Mlini in žage" - ("The dialect in the shadow of the Vertatscha. Mills and sawmills") (1994) - was initially only produced in Slovene. Public presentation of the documentary during a three-day careers fair in Klagenfurt showed that both Slovene-speaking and Germanspeaking visitors were highly interested in the video. This success motivated the project 
leader to immediately produce a dubbed German version - "Dialekt unter der Vertatscha. Mühlen und Sägen" (1994), which, like the original Slovene version, became a popular present at Christmas and on other occasions.

\section{2.}

From then on, two original versions - i.e. one in the Slovene and one in the German dialect - were produced of every video. This decision was taken in response to a very complex sociolinguistic situation encountered in Diex when a video on water mills was being recorded there in 1995: "Barbara, Luzia, hilf ... Wassermühlen" ("Barbara, Luzia, help us ... water mills in Diex"). In this area, located on the northernmost fringes of the Slovene-speaking parts of Carinthia, the project leader wanted to record the local Slovene vernacular on the occasion of the 1100th anniversary of the first historical documentation of the name "Diex", which, however, gave rise to considerable sociolinguistic problems. ${ }^{4}$ This is why it is interesting to look at this particular project in more detail, referring, amongst others, to the complicated statistics on which language(s) the bilingual population in this sensitive region actually admits to speaking.

\subsection{1.}

In the course of the past few decades, the young and middle-aged inhabitants of Diex have switched from Slovene to German, which keeps causing conflicts between the older and younger generations. The relevant statistical data clearly illustrate the changes undergone by the population of Diex in terms of language and identity. In 1880 Diex had 1,702 (96\%) Slovene-speaking inhabitants and only 75 (4\%) who spoke German. ${ }^{5}$ Linguistic and national political developments during the 1920s significantly influenced the official statistics: the share of the population speaking colloquial Slovene decreased from $1,404(87.7 \%)$ in 1910 to 428 (26.9\%) in 1923. Ibounig suggests a convincing explanation for this development:

"The collapse of the monarchy and, especially as far as Carinthia is concerned, the "Abwehrkampf" and the plebiscite did not remain without consequences. After 1920 the use of a particular language was interpreted as a declaration in favour of that nationality, more so than in the past, a situation which many who were Slovene only by dint of their language wanted to avoid. Many inhabitants who normally used Slovene rather than German in a mostly Slovene-speaking environment obviously stated that German was the language they used in their daily lives in order to emphasize their "German-Austrian" identity. As the census did not allow for people to indicate two languages - this option was only introduced later - they had to choose one or the other language as their everyday language; even though practically all inhabitants of the community were bilingual at the beginning of the 1920s, the choice was also influenced by national motives." ${ }^{6}$ 
In the 1991 census, the proportion of inhabitants in Diex who indicated that German was their colloquial language had already increased to $85.9 \%$, leaving $11.2 \%$ (105 persons) for Slovene and 2.9\% (27 persons) for Windisch. Collected using different methods under different conditions, the statistical data still give a clear signal, even though they do not render a true image of the actual situation.

\subsection{2.}

Considering these sociolinguistic conditions, it initially seemed almost impossible to record the Slovene dialect of Diex on video (cf. Maurer-Lausegger 1996, 1998, 2000a, 2001; Maurer-Lausegger/Kresitschnig/Verhounig 1996). The bilingual dialect speakers selected for the video refused to speak Slovene in front of the camera unless a version of the video was produced in German as well. They were, in fact, put under enormous ethnopsychological pressure by their own social environment. The demands formulated by the dialect speakers were finally met, and the video documentation was produced in two original versions.

The showing of the German version of the video about water mills, "Barbara, Luzia hilf ... " (1995), in Diex was welcomed with great interest both by the inhabitants of the village and the tourists staying in the region. On the same occasion a short extract from the Slovene version was presented as well. However, with the exception of church representatives, the inhabitants of the area are still largely afraid to admit their interest in the Slovene language in public, and the Slovene version has not yet been shown in an official capacity. However, we were informed that both the German and the Slovene versions of the video were passed on from home to home in Diex in autumn 1995 and watched with great interest in the safety of the villagers' own home. Even those who only have a passive knowledge of the Slovene vernacular or do not understand it altogether were at least able to identify with the visual part of the documentation.

Some months after the videos had been released, interviews with Carinthians revealed that the fact that the video had been produced in German and Slovene - i.e. in both of the languages spoken in Carinthia - in many instances improved people's attitudes towards the Slovene dialect, awakening interest in preserving the Slovene dialect. This favourable development was, of course, aided by a greater appreciation of Slovenia on the part of the Carinthian population (related to the advantages of shopping in Slovenia, amongst others). Today efforts are being made in Diex to preserve the bilingual character of the region, especially in the fields of culture and education. There is even some proof that the local Slovene dialect is being increasingly used for communication once again.

\section{3.}

The third issue in the video project arose in connection with the video on sheep breeding "Schafzucht ohne Grenzen. Sprachliche und volkskundliche Beobachtungen aus Südkärnten" - ("Sheep breeding without borders: linguistic and ethnographic observations in southern Carinthia. A contriburion to the Carinthian District Exhibition 1997") (1996). It 
documents the vernacular spoken in the Bodental region. Two originals versions (in Slovene and in German) were produced of the video which was presented to the general public at a special exhibition entitled "Dokumentation alter Volkskultur" in Bodental (17 May - 26 October 1997) on the occasion of the Carinthian District Exhibition in 1997. The bilingual video on sheep breeding was played throughout the day - supplementing an exhibition of old farm equipment, photographs illustrating the local folk culture and a pen of the Carinthian "spectacled" sheep themselves which are actually in danger of dying out - and will certainly be remembered by many visitors from Austria and abroad.

The central part of this special exhibition on ethnography concentrated on old farm equipment used by the inhabitants of Bodental and Windisch Bleiberg well into the 1950s and 1960s. The exhibits were numbered but not provided with labels stating their names. The visitors were asked to write down the dialect names of the equipment on display in a terminology catalogue provided for this purpose. The increasing interest in dialect in general and in old folk culture was proven by the fact that many different dialect names for the exhibits were indicated in the catalogue. By the end of the exhibition the terminology catalogue contained words and expressions from a great variety of different European languages and dialects.

During the six-month exhibition, a number of public events were organized in either one or both languages, depending on the audience. Many events ended with lively and constructive discussions on the issues of dialect and minority problems.

The ethnographic exhibition and the rural terminology were recorded on a video in Slovene dialect. The video entitled "Dokumentation alter Volkskultur" (Documentary records of past folk culture) has been shown in public several times. The exhibition of 1997 clearly fulfilled its sociocultural objectives and encouraged the organization of follow-up activities (such as recording the 1998 ethnographic exhibition on video).

\section{4 .}

The very successful exhibition on old farm implements held in the summer of 1997 in the Bodental valley, the numerous technical terms for the implements on display collected in various languages and especially the linguistic skills and expertise of the bilingual dialect speaker from Windisch Bleiberg/Slovenji Plajberk were the impetus for documenting the terminology collected for this exhibition in a video entitled "Orodje $s$ koroških podstrešij. Poden 1998" ("Farm implements from Carinthian lofts. Bodental 1998") which was filmed in late autumn in 1998. In the following summer a dubbed German version was produced which was not aimed at dialectologists but at the general public and people interested in folklore. 


\section{5.}

Cooperation with the professional film team on the "Documentary records of past folk culture in dialect" project, the successful development of a method of documenting dialectological and cultural matters in film and a very experienced cameraman proved to be an advantageous combination, and so work started on a second documentary on terminology entitled "O saneh ..." ("About sledges ...") in January 1999. The two documentaries in Slovene dialect on old farm implements (see 4.4.) and sledges were very well received by experts and the general public/media alike; consequently dubbed German versions were produced in autumn 1999 ("Über Schlitten ..." and "Bauerngerät von Kärntner Dachböden") and presented along with the accompanying pamphlet shortly after.

\section{6.}

The location and dialect speaker for the documentary "Kruh iz črne kuhinje" ("Bread from the black kitchen") (1999-2000) were discovered quite by chance when shooting the original version of the film on sledges. The surroundings of the traditional black kitchen and the dialect speaker were ideal for producing another ethnographic, dialectological documentary. The material for the original version in Slovene vernacular was filmed in the early summer of 1999 and it was completed in autumn of the same year along with the dubbed German version "Brot aus der Rauchküche" and the accompanying pamphlets. The results of the project were published and the first showing of the film took place in December 1999.

All of the projects listed here have been presented at numerous academic events and on a whole range of cultural occasions, always to an enthusiastic reception. Interest in the projects also came from abroad and so the documentaries on baking bread in the black kitchen and on sledges were provided with English subtitles in 2000 and 2001 respectively and published with an accompanying English text. Since then, the projects have been presented at international symposiums, lecture series and cultural events in many European countries and also in Japan, attracting the attention of the media. The presence of the project in the internet - www.kwfilm.com - which has been sponsored in a spirit of partnership by a German company since September 2000, has opened it up to a much wider audience. Finally, and maybe more importantly, the project has managed to break down the language barriers which existed initially and has been very successfully presented at a very wide range of public events in Carinthia.

\section{FINAL REMARKS}

Audiovisual documentation of ethnological issues regarding Slovene and German dialects in the bilingual regions of Carinthia has three goals: linguistic, cultural and sociocultural. On the one hand, the commercial video films awake the audience's interest in the province's rich cultural heritage from the past; on the other hand they contribute to improving relations between German and Slovene. Mutual appreciation of each other's culture and language is clearly increasing within the two ethnic groups 
in Carinthia. Amongst other things, this is due to generally improved relationships between the representatives of both cultures in the province. The sociocultural activities carried out within the project as well as the numerous presentations of the videos at bilingual cultural events in Carinthia strengthen the majority's loyalty towards the minority's language and culture and also draws attention to the fact that traditional and cultural values are in danger of disappearing forever. We can only hope that this positive development from which both ethnic groups benefit will continue in a Europe of different languages and cultures.

\section{REFERENCES}

Ibounig, Peter (1995), "Die sprachlichen Verhältnisse in Diex anhand der Volkszählung sergebnisse", in: Wlattnig (1995), pp. 115-118.

Filipič, Hanzi (1995), "Die politische Orientierung in der Gemeinde Diex/Djekše von 1880-1914“, in: Wlattnig (1995), pp. 125-130.

Križnar, Naško (1991), "Izhodišča vizualnih raziskav v etnologiji", Traditiones, Zbornik Inštituta za slovensko narodopsije, 20 (1991), pp. 143-162.

Maurer-Lausegger, Herta (1994), "Situationally-motivated speaking habits among Carinthian Slovenes“, Slovene Studies, 15/1-2 (1994), pp. 87-99.

Maurer-Lausegger, Herta (1995), “Videodokumentacija narečja. Izkušnje in sociolingvistični problemi na terenu dvojezične Koroške", in: Muršič, Rajko, Mojca Ramšak (Eds.) (1995), Razvoj slovenske etnologije od Štreklja in Murka do sodobnih etnoloških prizadevanj. Zbornik prispevkov s kongresa, Ljubljana: Knjižnica Glasnika SED 23, pp. 269-274.

Maurer-Lausegger, Herta (1996), “Die Mundart von Diex/Djekše in Kärnten. Eine zweisprachige Videodokumentation", in: Ohnheiser, Ingeborg (Hg.) (1996), Wechselbeziehungen zwischen slawischen Sprachen, Literaturen und Kulturen in Vergangenheit und Gegenwart, Innsbruck: Verlag des Instituts für Sprachwissenschaft, pp. 257-268.

Maurer-Lausegger, Herta (1997), “Filmska dokumentacija narečja. Metodologija spraševanja v dvojezični situaciji na južnem Koroškem“, in: Križnar, Naško (Ed.) (1997), Etnološki film med tradicijo in vizijo, Ljubljana: ZRC SAZU, pp. 141-150.

Maurer-Lausegger, Herta (1998), "Dialektforschung mit der Videokamera im südlichen Kärnten. Ein Bericht über Erfahrungen, Methoden und Probleme", in: Pittner, Karin, Robert Pittner (Hgg.) (1998), Beiträge zu Sprache und Sprachen 2. Vorträge der 5. Münchner Linguistik-Tage, München 1995, München, pp. 5-19.

Maurer-Lausegger, Herta (1999), "Videodialektološko zapisovanje govorov na Koroškem v Avstriji“, in: Zorko, Zinka, Mihaela Koletnik (Eds.) (1999), Logarjev zbornik. Referati s 1. mednarodnega dialektološkega simpozija v Mariboru. (Mednarodni dialektološki simpozij 1; 1996), Maribor: Slavistično društvo (Zora 8), pp. 318-326.

Maurer-Lausegger, Herta (2000), “Die audiovisuelle Dialektforschung - eine Kulturwissenschaft", in: Stadler, Wolfgang, Eva Binder, Helmut Kalb (Hgg.) (2000), Junge Slawistik in Österreich. Beiträge zum 1. Arbeitstreffen, Innsbruck, 24. - 26.02.1999, Innsbruck: Verlag des Instituts für Sprachwissenschaft, pp. 187-207.

Maurer-Lausegger, Herta (2000a), "Zur soziolinguistischen Situation in der gemischtsprachigen Gemeinde Diex/Djekše in Kärnten. Ein historischer Streifzug“, Plurilinguismo. Contatti di lingue e culture, 7 (2000), pp. 61-78. 
Maurer-Lausegger, Herta (2001), "Zur soziolinguistischen Situation in der gemischtsprachigen Gemeinde Diex/Djekše in Kärnten. Ein historischer Streifzug“, in: Pittner, Robert, Karin Pittner (Hgg.), Beiträge zu Sprache und Sprachen 3. Vorträge der 6. Münchner Linguistik-Tage, München, 25. - 27. März 1996, München, pp. 109-124.

Maurer-Lausegger, Herta (article in print), "Audiovisuelle Dialekt- und Terminologieforschung: Fragen zur Übersetzung und Synchronisation dialektologischer Filme".

Maurer-Lausegger, Herta, Gerhard Kresitschnig, Elfriede Verhounig (1996), "Ob 1100-letnici sončnih Djekš/Diex na avstrijskem Koroškem. Strnjena vaška kronika", Traditiones. Zbornik Inštituta za slovensko narodopisje, 25 (1996), pp. 273-295.

Moritsch, Andreas (1991), Vom Ethnos zur Nationalität. Der nationale Differenzierungsprozeß am Beispiel ausgewählter Orte in Kärnten und Burgenland, Wien, München: Verlag für Geschichte und Politik, R. Oldenbourg Verlag.

Pleterski, Janko (1996), Slowenisch oder deutsch? Nationale Differenzierungsprozesse in Kärnten (1848-1914) / Janko Pleterski. Bearb. u. Einl. von Valentin Sima. Deutschsprachige Erstausgabe, Klagenfurt: Drava Verlag.

Suppan, Arnold (1978), "Zwischen Assimilation und nationalpolitischer Emanzipation. Die Kärntner Slovenen vor und im Ersten Weltkrieg (1903-1918)", Österreichische Osthefte, 20 (1978), pp. 292-328.

Scheutz, Hans Peter, Robert Haudum (1982), "15. Theorieansätze einer kommunikativen Dialektologie", in: Besch, Werner (Hg.) (1982), Dialektologie. Ein Handbuch zur deutschen und allgemeinen Dialektforschung, 1. Halbband, Berlin, New York: De Gruyter, pp. 295315.

Wlattnig, Robert (Hg.) (1995), Diex. Sonnendorf auf der Saualpe, Klagenfurt: Heyn.

\section{OTHER SOURCES}

From our series: Dialektdokumentationen - Narečne dokumentacije (Documentaries in dialect), (C) Herta Maurer-Lausegger - www.kwfilm.com (University of Klagenfurt) - The project series is published by Hermagoras Verlag in Klagenfurt. Video cassettes and pamphlets are available at: Hermagoras Buchhandlung, Viktringer Ring 26, A-9020 Klagenfurt, Austria. Tel. ++43 (0) 463 56515-17; FAX: ++43 (0) 463 514189. E-mail: knjigarna@mohorjeva.at. Homepage: http://www.mohorjeva.at

\section{Video Cassettes}

1.1. Narečje pod Vrtačo. Mlini in žage. Dokumentacija. (original Slovene version; 20 min.), 1994.

1.2 Dialekt unter der Vertatscha. Mühlen und Sägen. (dubbed German version; 20 min.), 1994.

2.1 Barbara, Lucija, pomoj ... Prispevek k 1100-letnici sončnih Djekš. (original Slovene version; 19 min.), 1995; ISBN 3-85013-410-5.

3.1 Barbara, Luzia, hilf ... Ein Beitrag zur 1100-Jahr-Feier Diex. Wassermühlen. (original German version; 19 min.), 1995; ISBN 3-85013-411-3.

4.1 Schafzucht ohne Grenzen. Sprachliche und volkskundliche Beobachtungen aus Südkärnten. (original German version; 26 min.), 1996; ISBN 3-85013-501-2.

5.1 Bica bica, su su su ... Jezikovni in etnološki utrinki iz dvojezične Koroške. (original Slovene version; 28 min.), 1996; ISBN 3-85013-502-0. 
6.1 Orodje s koroških podstrešij. (original Slovene version; 30 min.), 1999; ISBN 385013-655-8.

6.2 Bauerngerät von Kärntner Dachböden. (dubbed German Version; 30 min.), 1999; ISBN 3-85013-683-3.

7.1 O saneh ... Über Schlitten ... (original Slovene version; 47 min.), 1999; ISBN 3-85013658-2.

7.2 Über Schlitten ... (dubbed German Version; 47 min.), 1999; ISBN 3-85013-684-1.

7.3 About slegdes ... (Slovene with English subtitles; 47 min.); 2001; ISBN 3-85013-7716.

8.1 Kruh iz črne kuhinje ... (original Slovene version; 25 min.), 1999; ISBN 3-85013-7082.

8.2 Brot aus der Rauchküche ... (dubbed German version; 25 min.), 1999; ISBN 3-85013709-0.

8.3 Bread from the black kitchen. (Slovene with English subtitles; 25 min.), 2000; ISBN 3-85013-773-2.

9.1 - 12.1 (videos in preparation, 2004).

\section{Pamphlets}

1.1.1 Narečje pod Vrtačo. Mlini in žage. Priloga videofilmu, 1994.

1.2.1 Dialekt unter der Vertatscha. Mühlen und Sägen. Beilage zum Videofilm, 1994; ISBN 3-85013-396-6.

2.1.1 Barbara, Lucija, pomoj ... Prispevek k 1100 letnici sončnih Djekš. Priloga videofilmu, 1998; ISBN 3-85013-412-1.

2.1.2 Barbara, Lucija, pomoj ... Ein Beitrag zur 1100-Jahr-Feier Diex. Beilage zum Videofilm, 1999; ISBN 3-85013-413-X.

5.1.1 Bica, bica, su su su ... Priloga videofilmu, 1999; ISBN 3-85013-663-9.

5.1.2 Bica, bica, su su su ... Beilage zum Videofilm, 2004; ISBN 3-85013-664-7.

6.1.1 Orodje s koroških podstrešij. Priloga videofilmu, 1999; ISBN 3-85013-656-6.

6.1.2 Bauerngerät von Kärntner Dachböden. Beilage zum Videofilm, 1999; ISBN 385013-657-4 .

7.1.1 O saneh ... Über Schlitten .. Priloga videofilmu, 2nd ed. 1999; ISBN 3-85013-6825.

7.1.2 Über Schlitten ... Beilage zum Videofilm, 2000; ISBN 3-85013-660-4.

7.1.3 About slegdes ... Pamphlet accompanying the video film, 2001; ISBN 3-85013-7724.

8.1.1 Kruh iz črne kuhinje. Priloga videofilmu, 1999; ISBN 3-85013-710-4.

8.1.2 Brot aus der Rauchküche. Beilage zum Videofilm, 1999; ISBN 3-85013-711-2.

8.1.3 Bread from the black kitchen. Pamphlet accompanying the video film, 2000; ISBN 3-85013-774-0.

9.1.1 - 12.1.1 (pamphlets in preparation, 2004). 


\section{Notes}

1 Until well into the first half of the 19th century, the term "Windisch" was used to refer to the Slovene language. It was replaced by "Slovene" in all crown lands at the time of Slovene national rebirth. In German dialects in the area, however, "Windisch" continued to be used. Cf. Suppan (1978: 324).

2 The original definition is as follows: "Der Einsatz der Videotechnik in der dialektologischen Feldforschung stellt ein sprach- und kulturwissenschaftliches Dokumentationsverfahren dar, das in synchroner Weise die auditive Wahrnehmung von Mundart, sonstigen Lauten und Geräusch und die visuelle Betrachtung der spontanen Artikulation unter Einschluß von nonverbaler Kommunikation und kontextbezogenen sozialen Zusammenhängen aus realitätsnaher Perspektive ermöglicht. Die chronologisch ablaufenden Bildsequenzen auf dem Videoband sind reproduzierbar, so daß dieser Wahrnehmungs- und Beobachtungsprozeß an jedem beliebigen Ort, wo die technischen Voraussetzungen gegeben sind, und zu jedem beliebigen Zeitpunkt wiedererlebt und nachvollzogen werden kann. Je öfter und intensiver dieser Prozeß stattfindet, desto tiefer läßt sich dieser realitätsnahe Kontext erschließen“ (Maurer-Lausegger 2000: 191f.).

4 For more details, see Wlattnig (1995), Maurer-Lausegger (1996, 2000a, 2001); Maurer-Lausegger/Kresitschnig/Verhounig (1996).

5 The statistical data quoted on languages spoken is based on the table "Die umgangssprachliche Entwicklung in der Gemeinde Diex von 1880 bis 1991 (Colloquial language development in the community of Diex between 1880 and 1991)", Ibounig (1995: 117). Towards the end of 1910 the Catholic Political and Agricultural Association of Slovenes in Carinthia conducted a private census by colloquial language and nationality to verify the results of the official census. The results astonished the Slovene population: 135,415 persons, i.e. a plus of more than 50,000 Carinthian Slovenes. Quoted from Suppan (1978: 293f.). For more details about the process of national differentiation in bilingual Carinthia, see Moritsch (1991), Pleterski (1996).

6 Quoted from Ibounig (1995: 116), translated by the author og this paper. For more details, see Filipič (1995). 